\title{
Pendampingan Pengembangan Potensi Bidang Bahasa, Seni Sastra, dan Seni Pertunjukan Jawa di Desa Beji Kecamatan Ngawen Kabupaten Gunungkidul Menuju Desa Berbudaya Jawa ${ }^{1}$
}

\section{Djarot Heru Santosa}

Prodi Sastra Jawa, Departemen Bahasa dan Sastra, Fakultas Ilmu Budaya, UGM Email:djarot_gg@ugm.ac.id

Tim pengabdian kepada masyarakat:

Djarot Heru Santosa, Arsanti Wulandari, Sumarsih, Kartika Setyowati, Marsono, Hendrokumoro, Anung Tedjowirawan,Sulistyowati, Soeharto Mangkusudarmo, R. Bima Slamet Raharja, Sri Ratna Saktimulya, Daru Winarti, Akhmad Nugraha, M. Bagus Febrianto, Rudi Wiratama, Wisma Nugraha Ch., Wiwien Widyawati Rahayu, Ngamiludin

\begin{abstract}
Abstrak
Sebuah desa yang memiliki potensi di bidang budaya, khususnya bahasa, sastra, dan seni pertunjukan tidak mudah ditemukan dalam era tahun milenium ini. Ketika kondisi tersebut dimiliki oleh desa tertentu, sudah sewajarnya perlu didampingi untuk menumbuhkan dan memperkuat kesadaran diri pemilik, dengan cara mempertahankan, melestarikan dan tentu saja mengembangkan potensi itu. Salah satu desa yang memiliki potensi di bidang budaya Jawa, khususnya bahasa, sastra, dan seni pertunjukan tersebut adalah Desa Beji. Lokasi desa ini terletak di wilayah Kecamatan Ngawen Kabupaten Gunungkidul DIY.

Metode pendampingan ini dilakukan dengan cara observasi dan inventarisasi masalah, pemetaan permasalahan, melakukan tindakan (action) berupa pemberian motivasi, penyuluhan, edukasi, dan membuka seluas-luasnya diskusi dan konsultasi. Berdasar metode pelaksanaan pengabdian ini diharapkan hasil yang dicapai bisa optimal, yaitu perubahan perilaku masyarakat dalam hal kesadaran, peningkatan pemahaman, dan kesanggupan untuk mengelola potensi bidang bahasa, sastra, dan seni pertunjukan yang sudah dimilikinya.

Hasil dari pengabdian masyarakat di Desa Beji khususnya di bidang bahasa adalah ditemukan beberapa kesalahan dan ketidaktepatan penggunan ragam bahasa Jawa dalam kehidupan sehari-hari. Selain itu juga berhasil dilakukan koreksi dan edukasi penulisan huruf Jawa dalam papan nama di dusun-dusun. Di bidang sastra, bersama-sama masyarakat berhasil mendokumentasi penulisan cerita-cerita rakyat berdasar beberapa lokasi peninggalan sejarah yang terdapat di desa tersebut. Di bidang seni pertunjukan, selain berhasil dalam edukasi dan penyuluhan juga pembentukan kelembagaan kelompok seni yang ada di desa Beji.
\end{abstract}

Kata kunci: pendampingan, pengembangan, potensi budaya, Jawa

1) Disarikan dari hasil kegiatan Tim pengabdian kepada masyarakat Prodi Sasra Jawa, Departemen Bahasa dan Sastra, Fakultas Ilmu Budaya, Universitas Gadjah Mada, tahun 2017. 


\begin{abstract}
A village having potential of cultures, especially language, literature, and performing arts is getting more difficult to be found in this millenium era. When the condition is owned by a certain village, it is natural to be accompanied in growing and strengthening the self-awareness of the villagers by maintaining, preserving, and developing those potentials. One of the villages that has potential of Javanese cultures, especially language, literature, and performing arts is Beji Village. The location of the village is in Ngawen District, Gunungkidul, DIY.

Observation and inventory of problems, mapping the problems, taking action in the form of giving motivation, counseling, education, and opening the discussion and consultation as widely as possible are the methods of the accompaniment. By implementing those methods, optimal results namely changes in community behavior in terms of awareness, understanding improvement, and capability to manage the potential field of language, literature, and performing arts that they already have will be achieved.

The result of community service in Beji Village, especially in the field of language shows some errors and inaccurate uses of the Javanese variety language in daily routine. In addition, there was also some correction and education in writing Java letters in the nameplate in the sub villages. In the literature field, accompanied by the local society, we succeeded in documenting the writing of folklore based on some heritage sites in the village. In performing arts, not only succeeding in education and counseling, we also established the institutional art groups in the village of Beji.
\end{abstract}

Keywords: mentoring, development, cultural potential, Java

\title{
Latar Belakang
}

Desa Beji merupakan salah satu desa yang terletak di wilayah Kecamatan Ngawen, Kabupaten Gunungkidul, Provinsi Daerah Istimewa Yogyakarta. Desa ini terletak di sisi sebelah utara wilayah kabupaten Gunungkidul. Kondisi desa ini relatif subur meskipun konturnya tidak datar. Mata pencaharian masyarakatnya adalah di bidang pertanian dan perdagangan (Suliantoro, B.W., 2014:57).

Kondisi sosial geografis wilayah Desa Beji terdiri dari 14 pedusunan, kondisi sosial politik dan perkonomian masyarakatnya cukup baik dan kondusif. Hubungan sosial kemasyarakatan di desa ini masih sangat menjunjung tinggi adat dan budaya Jawa. Sifat kegotongroyongan dan kerukunan antar masyarakat masih dijunjung tinggi. Berdasarkan informasi dari data stastistik Pemerintahan Daerah Kecamatan Ngawen tahun 2015, Desa Beji memiliki kepadatan penduduk kurang dari 450 jiwa $/ \mathrm{km}^{2}$ Rendahnya nilai kepadatan penduduk Desa Beji menunjukkan bahwa Desa ini bukan daerah padat penduduk, melainkan masih banyak tersedia lahan kosong. Hal ini disebabkan oleh hadirnya hutan adat di wilayah ini. Lahan di Desa Beji paling besar berupa hutan negara atau yang dikenal sebagai Hutan Wonosadi (Badan Pusat Statistik. 2015).

Di bidang kebudayaan, Desa Beji ini memiliki potensi budaya yang beragam dan masih sangat kental dengan kehidupan sehari-hari masyarakat Desa Beji. Potensi budaya, khususnya seni pertunjukan diantaranya terdapat seni rinding gumbeng, watu gedhong, dan juga kali ndek. Kesenian rinding gumbeng merupakan suatu cerminan dari masyarakat sekitar yang ada di Kabupaten Gunungkidul yang sederhana, ulet, dan dekat dengan alam dimana yang memadukan antara dua alat musik yaitu rinding dan gumbeng.

Di bidang seni sastra, keberadaan cerita dan mitos-mitos yang beredar di masyarakat Desa Beji masih sangat kuat. Keberadaan hutan desa yang dianggap wingit 'angker' oleh 
masyarakat setempat memunculkan berbagai cerita rakyat yang cukup menarik untuk didokumentasikan dan dikaji. Seiring hal tersebut, masih dilestarikannya kegiatan tradisi nyadran setiap tahunnya dapat menunjukkan bahwa tradisi budaya adat Jawa masih dijunjung tinggi masyarakat desa ini. Sementara itu sinergi antara Mitos yang beredar di masyarakat dengan pelestarian hutan adat di Desa Beji juga berperan penting dalam kehidupan masyarakat setempat.

Di bidang bahasa, khususnya bahasa Jawa, masih diminati oleh sebagian besar penduduk di desa ini sebagai alat komunikasi sehari-hari maupun difungsikan sebagai alat pengungkap ekspresi diri. Kekhawatiran lunturnya penggunaan bahasa Jawa di kalangan generasi muda perlu segera diatasi dengan mendatangkan para pakar di bidang ini untuk membantu menumbuhkan minat berbahasa Jawa yang baik dan benar, termasuk penggunaan bahasa Jawa dalam kegiatan pranatacara.

Hal-hal di bidang adat Jawa, seni pertunjukan, seni sastra, dan bahasa Jawa inilah yang akan menjadi titik tolak kegiatan pengabdian Prodi Sastra Jawa Departemen Bahasa dan Sastra Fakultas Ilmu Budaya Universitas Gadjah Mada Yogyakarta. Berdasarkan pada analisis situasi yang telah dipaparkan sebelumnya, Desa Beji yang berada di Kecamatan Ngawen, Kabupaten Gunungkidul memiliki potensi sumber daya manusia yang melimpah, khususnya dibidang seni dan budaya Jawa. Sumber daya dan potensi budaya Jawa ini, jika dipertahankan, dilestarikan dan dikembangkan akan menghasilkan suatu desa yang mandiri dan memiliki identitas yang kuat di bidang Budaya Jawa.

Berdasarkan potensi-potensi yang dimiliki oleh Desa Beji tersebut, Prodi Sastra Jawa merasa terpanggil untuk memberi pendampingan. Kegiatan yang dilaksanakan pada bulan April 2017 yang lalu ini diaktualisasikan dan difokuskan pada pemberian FGD (focus group discussion) di bidang Seni pertunjukan, Seni Sastra, Bahasa, dan tatanan adat tradisi budaya Jawa lainnya. FGD di bidang seni pertunjukan dalam hal pendataan potensi, organisasi kelompok seni, dan pengembangan pementasan. Di bidang seni pertunjukan ini, pada awalnya diarahkan untuk mengangkat kembali seni pertunjukan tradisional bernama Rinding. Kegiatan lainnya ditujukan kepada anak-anak dan remaja untuk melestarikan lagu-lagu dolanan dan permainan tradisional.

FGD di bidang seni sastra dalam hal pendataan potensi ragam cerita lisan dan penulisan cerita lisan. Dilakukan dengan mengajak para tokoh-tokoh dan narasumber yang layak untuk diambil data wawancara. FGD di bidang adat tradisi Jawa, memberi penyuluhan dan pemaparan berbagai upacara adat Jawa, seperti Selamatan, Rasulan, sedekah bumi dan lainnya. FGD di bidang bahasa, dalam hal penggunaan sebagai bahasa percakapan sehari-hari, pidato bahasa Jawa, dan pranatacara

Tujuan dari pengabdian Prodi Sastra Jawa di Desa Beji Kecamatan Ngawen Kabupaten Gunungkidul adalah, di antaranya merintis Desa Beji menjadi desa binaan berbasis Budaya Jawa melalui pendekatan community development, partisipatif, persuasif, dan edukatif. Harapan berikutnya, didorong terbentuknya kelompok masyarakat pengelola potensi seni budaya Jawa di Desa Beji, Kecamatan Ngawen, Kabupaten Gunungkidul.

Luaran yang akan dihasilkan dalam kegiatan ini adalah Desa Beji sebagai Desa Binaan Prodi, khususnya dalam mewujudkan Desa Beji sebagai Desa Wisata dengan khas Desa Beradat Budaya Jawa. Untuk mencapainya, diawali beberapa kegiatan dengan luaran jangka pendek seperti memiliki keinginan terbentuknya kelembagaan dalam 
pengelolaan potensi seni budaya Jawa. Luaran lain adalah terbentuknya kelompok masyarakat seni budaya yang dapat mengemas potensi seni dan budaya yang ada di Desa Beji. Kelompok masyarakat pecinta bahasa dan budaya Jawa ini sangat dinantikan hadir di tengah-tengah masyarakat.

\section{Metode}

Untuk mencapai tujuan dari program desa binaan tersebut di Desa Beji maka diperlukan langkah awal berupa transformasi ilmu pengetahuan di bidang tersebut dengan melibatkan seluruh elemen terkait. Agar transformasi dapat terwujud, diperlukan juga pemahaman terhadap kondisi masyarakat di Desa Beji. Hal ini dilakukan agar tidak terjadi kesalahpahaman antara Tim Pengabdian dan masyarakat. Adapun rancangan tahapan berkelanjutan program yang akan dilaksanakan untuk mencapai tujuan yang dimaksud, seperti terlihat pada diagram alir berikut.

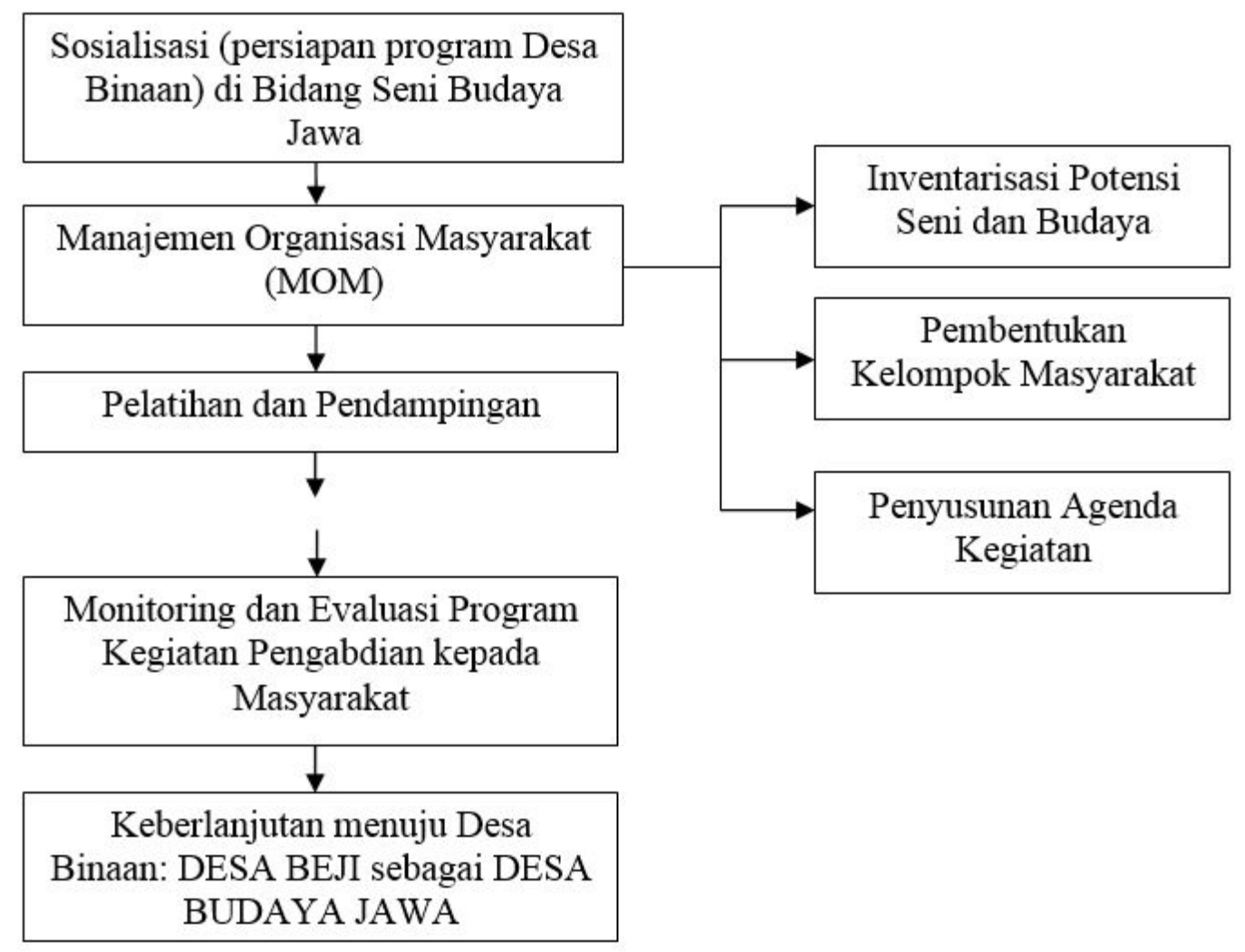

Diagram 1. Bagan alir Tahapan Kegiatan Pengabdian kepada Masyarakat Desa Beji Kecamatan Ngawen Gunungkidul sebagai Desa Budaya Jawa.

Tahap-tahap Pelaksanaan Pengabdian kepada masyarakat di bidang ini dilakukan dengan perencanaan kegiatan, mengurus perizinan karena menyangkut beberapa mitra yang terlibat. Untuk tahap berikutnya melakukan persiapan, sosialisasi dan pengumpulan bahan. Dilanjutkan dengan pelaksanaan kegiatan dan diakhiri tahap monitoring dan evaluasi hasil kegiatan menuju keberlanjutan program. 


\section{Tahap Perencanaan}

Kegiatan pengabdian ini diawali dengan penyusunan rencana kegiatan dan pembuatan proposal kegiatan. Setelah itu melakukan pertemuan-pertemuan informal terhadap pimpinan wilayah, masyarakat, dan unsur-unsur pendukung lainnya. Pada tahap ini, Prodi juga menyiapkan tim narasumber dan materi yang dapat digunakan dalam kegiatan pengabdian di lapangan.

\section{Tahap Perizinan}

Setelah proposal kegiatan disetujui, kegiatan selanjutnya adalah mengurus periinan, yaitu ke Pemerintah Kabupaten, Kecamatan dan Desa. Salah satu bekal syarat dalam pengurusan izin ini, terlihat di lampiran proposal ini berupa surat kesediaan Desa sebagai lokasi kegiatan pengabdian prodi.

\section{Tahap Sosialisasi}

Pada tahap ini dilakukan aktivitas sosialisasi internal dan eksternal. Secara internal, sosialisasi kegiatan pengabdian dilakukan melalui rapat-rapat persiapan dan merekrut mahasiswa untuk terlibat dalam kegiatan ini. Sosialisasi eksternal dilakukan dengan bekerjasama dengan aparat pemerintah Desa Beji untuk menyiapkan peserta yang terlibat, tempat pelaksanaan, perlengkapan, dan persiapan lainnya.

\section{Tahap Pelaksanaan}

Di luar kegiatan persiapan, pelaksanaan kegiatan ini dilakukan dalam waktu efektif 2 (dua) hari di Balai Desa Beji dan wilayah sekitarnya. Pelaksanaannya melalui kegiatan pelatihan dan pendampingan. Kegiatan pelatihan dan pendampingan ini diharapkan proses penyadaran, pengelolaan, dan pengembangan potensi seni dan budaya dapat berlangsung dengan efektif. Hal ini perlu dilakukan demi keberlangsungan program yang berkorelasi, mengingat pihak Tim Pengabdian tidak bisa terus-menerus melakukan kontroling, sehingga nantinya akan tercipta masyarakat yang mendiri dalam melanjutkan program Desa Binaan.

\section{Monitoring Keberlanjutan Program kepada Tim Pengabdian Masyarakat untuk Persiapan menjadi Desa Binaan}

Tahap monitoring dilakukan agar proses keberlanjutan kegiatan ini dapat berlangsung dengan baik. Tim Pengelola dari masyarakat tentunya masih membutuhkan bimbingan dalam proses pelaksanaan program. Dengan demikian, tujuan dari tahap monitoring adalah sebagai berikut:

- Melihat perkembangan program yang telah dilaksanakan

- Mengetahui kendala yang ada dalam proses pelaksanaan program

- Mencari solusi terhadap masalah yang ada, sehingga rencana program Desa Binaan yang dilaksanakan efektif dan bersinergis.

\section{Tahap Pelaporan}

Pada Tahap ini, Tim Pengabdian Prodi menyusun laporan hasil kegiatan, sekaligus menyusun dokumentasi kegiatan guna keperluan administrasi dan evaluasi kegiatan. Umpan balik dari hasil pelaporan ini diperlukan untuk kelanjutan manfaat pengabdian. 
Kegiatan Pengabdian kepada masyarakat juga memerlukan perhatian dalam hal keberlanjutan kegiatan atau program-programnya. Keberlanjutan program desa binaan Prodi ini didasarkan dari hasil tahapan evaluasi dan monitoring yang bertujuan untuk melihat perkembangan program yang telah dilaksanakan, mengetahui kendala yang ada dalam proses pelaksanaan program, dan mencari solusi terhadap masalah yang ada.

\section{Pembahasan}

Kegiatan pengabdian kepada Masyarakat untuk pendampingan masyarakat Desa Beji menuju Desa Budaya Jawa, dilakukan oleh tim Prodi Sastra Jawa dengan melakukan persiapan serius dan waktu yang panjang. Persiapan ini dilakukan selain pengurusan izin administrasi dan sosialisasi, juga mempersiapkan tim mahasiswa prodi sebagai tenaga sukarela untuk menyukseskan kegiatan. Sebanyak 10 - 15 mahasiswa prodi disiapkan dengan pembagian tugas masing-masing sebagai tenaga pendamping (tutorial kegiatan). Tim juga mempersiapkan para narasumber untuk menjadi penyuluh atau narasumber dalam FGD masing-masing bidang kegiatan. Para narasumber tersebut adalah para ahli di bidang bahasa Jawa (linguistik Jawa), penulisan huruf Jawa, sastra Jawa khususnya sastra lisan, ahli pranatacara Jawa, ahli pranatan Jawa, serta ahli di bidang seni pertunjukan Jawa, baik tradisional maupun moderen.

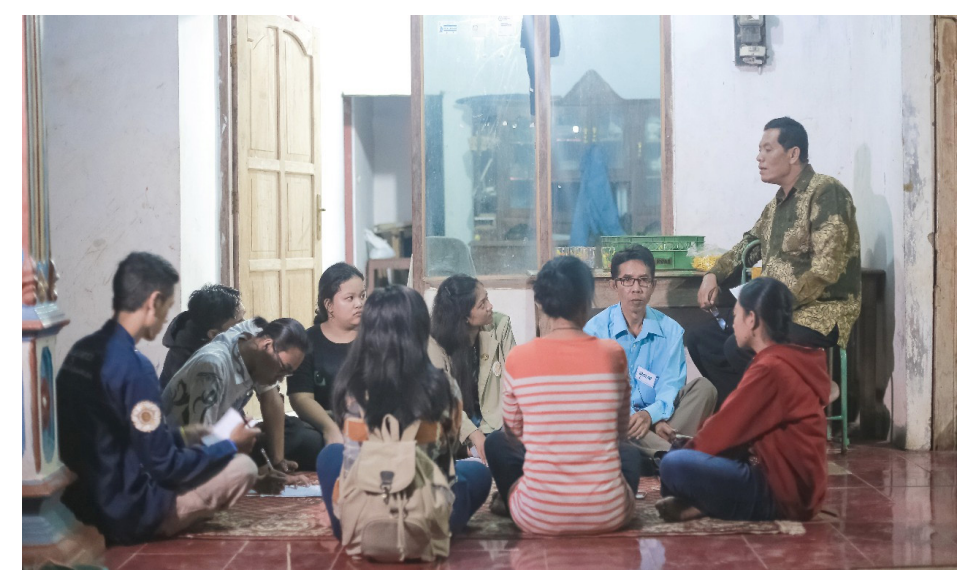

Foto 1. Persiapan Tim Mahasiswa

Kegiatan persiapan lainnya adalah menyiapkan bahan-bahan sebagai materi FGD maupun contoh-contoh di setiap bidangnya. Bahan-bahan ini pun juga dibagikan kepada masyarakat untuk bisa dipelajari lebih mendalam. Keistimewaannya adalah bahan ini diberikan kepada masyarakat sebelum kegiatan pelaksanaan berlangsung. $\mathrm{Hal}$ ini dimaksudkan agar pada pelaksanaan sudah fokus dan diperoleh hasil optimal.

Berikut pembahasan kegiatan pengabdian kepada masyarakat yang meliputi bidang per bidang kegiatan.

\section{Pengembangan potensi budaya Jawa secara umum}

Di bidang budaya Jawa, masyarakat Desa Beji masih mengenal ritual-ritual tradisional 
antara lain upacara-upacara adat seperti: kelahiran, perkawinan, dan kematian. Di samping itu mereka juga mewarisi upacara labuh yaitu upacara mulai menanam padi, sampai upacara panen yang disebut Mboyong Dewi Sri (membawa Dewi Sri atau Dewi Padi dari sawah ke rumah. Upacara pesta panen yang lain yang masih dilaksanakan hingga kini disebut Bersih Dusun atau Sedekah Bumi atau Rasulan.

Ritual adat Jawa yang paling populer bagi masyarakat Desa Beji adalah yang berhubungan dengan eksistensi hutan Wonosadi adalah Sadranan Wonosadi. Hutan yang menempati sebagian besar wilayah desa ini. Menurut kepercayaan masyarakat setempat, diyakini bahwa terdapat tokoh legenda bernama Ki Onggoloco yang masih menetap dan menguasai hutan Wonosadi sampai sekarang. Tokoh ini pernah menyampaikan pesan terakhir tentang perlunya diadakannya pertemuan di akhir panen pada hari Senin Legi atau Kamis Legi di sekitar wilayah hutan, Pemerintah desa Beji secara turun-temurun meresponnya dengan menyelenggarakan kegiatan-kegiatan ritual-ritual adat.

Wujud kegiatan ritual seperti ini sebagai suatu bentuk/model komunikasi sosial yang positif bagi masyarakatnya. Seiring waktu, kegiatan ritual adat Desa Wanasadi ini dilakukan dengan membentuk kepanitiaan modern yang disesuaikan dengan jamannya. Kegiatan ini disebut Upacara Adat Sadranan. Upacara adat ini dilakukan di dua tempat bertapa kedua mantan senopati Majapahit, yaitu di hutan Wonosadi dan Gunung Gambar. Kegiatan tersebut biasanya dihadiri banyak orang. Sebagai penyelenggara kegiatan terutama warga Duren dan Sidorejo, tetapi seluruh desa Beji juga mengikuti kegiatan ini.

Kegiatan ini tidak hanya diikuti oleh warga Beji, banyak warga luar daerah ikut nyadran. Kegiatan nyadran ditandai oleh datangnya orang-orang ke makam atau tempat tertentu untuk melakukan ziarah atau ritual tertentu untuk para leluhurnya. Biasanya keikutsertaannya karena adanya kepercayaan bahwa keinginannya sudah terpenuhi.

Hutan Wonosadi juga dikenal membawa berkah sehingga ada sebagian warga yang mempercayai doa dan keinginan dapat dikabulkan oleh 'penguasa' Wonosadi. Sadranan Wonosadi juga menjadi pembuka bagi diadakannya ritul-ritual desa yang lingkupnya lebih kecil. Dalam kegiatan-kegiatan tersebut juga dimainkan kesenian Rinding Gumbeng. Seni ini diklaim sebagai seni khas Wonosadi Beji. Seni ini menampilkan pertunjukan musik dari alat yang sebagian besar terbuat dari bambu dan dawai. Ketika musik Rinding Gumbeng ditampilkan membuat suasana khas yang bisa membikin merinding bagi yang mendengarnya. Suasana yang ditimbulkan menambah keangkeran suasana hutan. Keangkeran hutan Wonosadi masih menjadi hal yang dipertimbangkan apabila anggota masyarakat akan melakukan hal-hal yang di luar kebiasaan adat. Hal ini menyebabkan tidak adanya anggota masyarakat yang berani merusak hutan.

Situasi dan kondisi Desa Beji yang bernuansa Budaya Jawa yang kuat ini, mendorong Pemerintah Kabupaten Gunung Kidul Yogyakarta mulai tahun 2013 mulai menggarap tujuan wisata baru berbasis lingkungan (eko-wisata) di komplek Hutan Adat Wonosadi, Desa Beji, Kecamatan Ngawen, Kabupaten Gunung Kidul. Hutan Wonosadi sendiri saat ini telah tercatat sebagai kawasan hutan konservasi. Artinya seluruh flora dan fauna yang ada di hutan itu sudah dipastikan dilindungi dan dilarang keras untuk diburu, dibawa keluar hutan, dan kepentingan lain yang sifatnya komersial (Winastuti, 2016:7). 


\section{Pengembangan Potensi Bidang Bahasa Jawa}

Kegiatan pendampingan pengembangan potensi dalam bidang bahasa Jawa di masyarakat Desa Beji dilakukan dengan penyuluhan, FGD, dan praktik langsung. Materinya adalah dalam hal penggunaan kosa kata bahasa Jawa dalam ragam krama dan krama inggil, koreksi penulisan nama-nama dusun dan tempat lainnya dalam papan nama yang bertuliskan huruf Jawa, dan diskusi tentang kosa kata bahasa Jawa lainnya.

Hasil kegiatan di bidang ini, Prodi Sastra Jawa menyerahkan beberapa materi yang bisa dipelajari sendiri oleh komunitas masyarakat setempat, dan juga beberapa pedoman penulisan Ejaan Bahasa Jawa yang sudah disempurnakan.

Di bidang penguasaan bahasa Jawa ini, juga disampaikan materi-materi yang berhubungan dengan kegiatan pranatacara atau pembawa acara dan pidato-pidato yang menggunakan bahasa Jawa ragam Krama dan Krama Inggil. Materi pelatihan dan praktik di bidang ini untuk memenuhi keinginan masyarakat. Tradisi penggunaan bahasa Jawa untuk keperluan pembawa acara dan pidato berbahasa Jawa yang baik dan benar ini menjadi sangat penting dalam mendukung suasana desa ini menuju Desa Berbudaya Jawa.

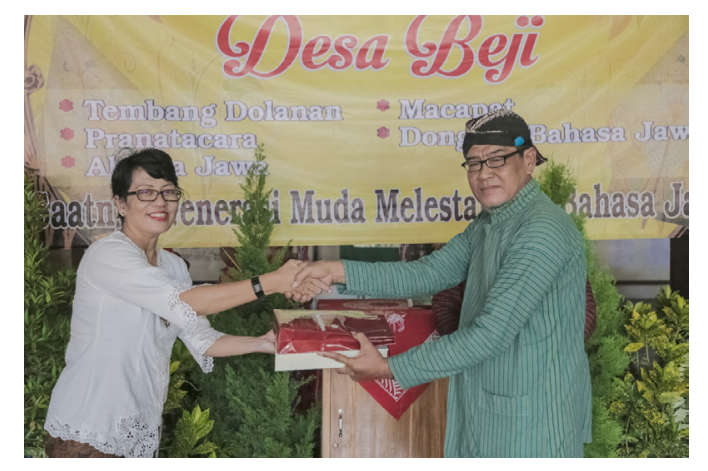

Foto 2. Foto dokumentasi penyerahan materi di bidang pengembangan Bahasa Jawa bagi Masyarakat Desa Beji

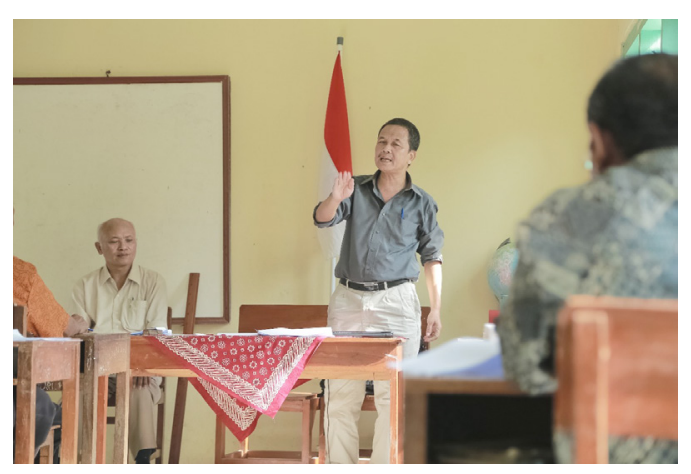

Foto 3. Narasumber Prodi Sastra Jawa sedang memberi pelatihan menjadi pembawa acara dan pidato berbahasa Jawa dengan baik dan benar

\section{Pengembangan Potensi Bidang Seni Sastra}

Pendampingan di bidang ini dilakukan berawal dari keinginan masyarakat wilayah Desa Beji ini untuk mengumpulkan dan mendokumentasi beberapa cerita rakyat yang muncul dari kondisi yang berada di lingkungannya. Berdasarkan tradisi kuat adat Jawa yang telah dijalankan masyarakat, ditimbulkan dari kepercayaan masyarakat yang turun-temurun melalui mulut ke mulut berupa cerita-cerita yang mengarah ke mitos tokoh tertentu. 
Cerita-cerita itu dihubungkan dengan kepemilikan wilayah Hutan Wonosadi di desa tersebut dan beberapa peninggalan Kraton Surakarta, di antaranya Situs Watu Gendhong, Watu Sepikul, Watu Gembok, bangunan Pura, dan sebagainya. Kondisi ini menghasilkan cerita lisan seperti Cerita Kisah Eyang Carik, Cerita Onggoloco dan Rara Resmi, Cerita Watu Pundhen, Cerita Watu Segendhong dan Watu Sepikul. Bentuk cerita rakyat ini terdapat berbagai macam variasi cerita, hal ini tidak menjadi masalah karena memang sudah menjadi ciri khas cerita lisan.

Kesadaran akan memiliki cerita rakyat yang menarik tersebut, masyarakat ingin mendokumentasi ke dalam bentuk tulis yang nantinya bisa diwariskan kepada anak cucu. Tim pengabdian Prodi Sastra Jawa bidang sastra mendampingi untuk dokumentasi dan penyusunan cerita rakyat Desa Beji ini dengan cara:

- Mengumpulkan data-data awal sebagai bahan untuk langkah selanjutnya;

- Menyusun draft garis besar alur cerita;

- Menyusun daftar wawancara narasumber;

- Pada waktu pelaksanaan pengabdian, mengumpulkan tokoh dan narasumber untuk wawancara, tim juga mencari data secara acak dan tersamar kepada masyarakat sekitar agar diperoleh keseimbangan informasi;

- Bersama tokoh masyarakat setempat menyusun hasil wawancara dan acuan bebeberapa sumber;

- Menyusun draft cerita rakyat Desa Beji;

- Mempublikasikan terbatas;

- Sebagai tindaklanjut akan diterbitkan secara luas dan diberikan kepada lingkungan masyarakat setempat, khususnya generasi muda atau anak-anak di sekolah-sekolah di Desa Beji maupun di lingkungan wilayah Kecamatan Ngawen Gunungkidul.

- Di masa yang akan datang, cerita rakyat Desa Beji ini dikembangkan untuk ditulis dengan gambar seperti bentuk komik, bahkan dimungkinkan dalam bentuk animasi sederhana. Hal ini di samping untuk lebih mempopulerkan juga mudah dipahami oleh generasi yang akan datang.

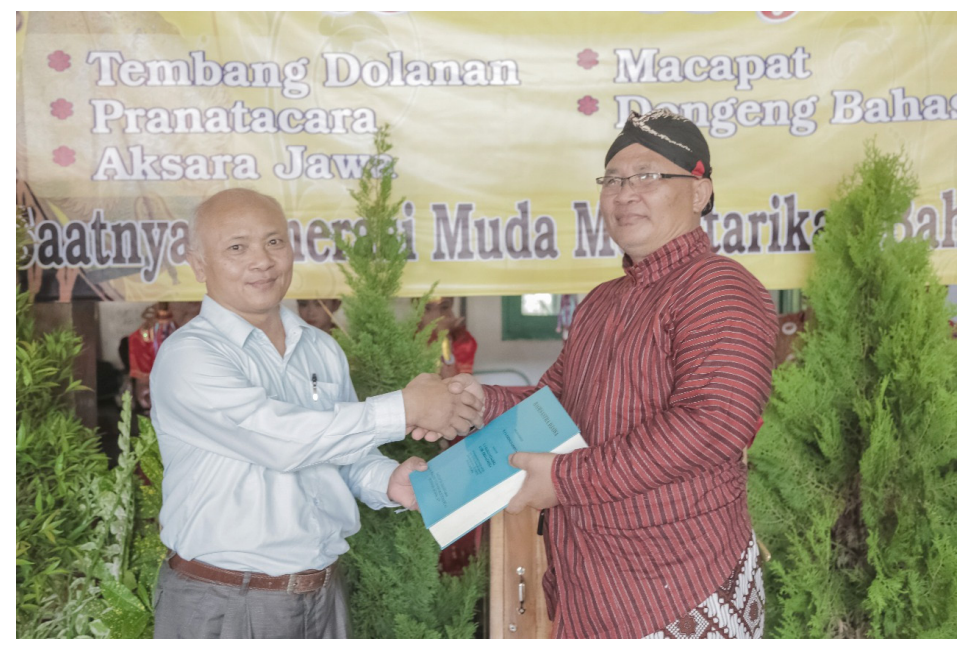

Foto 4. Penyerahan dokumen cerita rakyat Desa Baji oleh Tim Prodi Sastra Jawa sebagai langkah awal pendampingan di bidang ini 


\section{Pengembangan Potensi Bidang Seni Pertunjukan}

Di bidang seni pertunjukan, Desa Beji memiliki banyak kegiatan-kegiatan kelompok di seni ini, khususnya seni tradisional. Kelompok seni itu diantaranya Kelompok Karawitan, Kelompok Ketoprak, Dalang Wayang Kulit, Kelompok seni Jaran Kepang, Kuda Lumping, Rinding Gumbeng dan lainnya. Dari semua potensi seni pertunjukan yang dimiliki, warga Desa Beji sangat membanggakan seni pertunjukan Rinding Gumbeng.

Kalangan tua dan muda menikmati pertunjukan Rinding Gumbeng yang bisanya ditampilkan dalam kegiatan adat tradisi, seperti waktu bersih desa, Rasulan, nyadran dan lainnya. Pada akhir-akhir ini Rinding Gumbeng sering ditampilkan untuk menyambut tamu wisatawan yang berkunjung ke wisata Wanasadi. Keistimewaan Rinding Gumbeng ini adalah suara yang dihasilkan membuat suasana yang bisa menyayat hati.

Selain pendampingan di bidang seni pertunjukan tradisional, tim pengabdian kepada masyarakat Sastra Jawa juga melihat potensi besar di bidang ini pada anak-anak dan remaja warga Desa Beji. Berdasarkan kondisi ini, bersama mitra tenaga pendamping desa bidang budaya menyelenggarakan pelatihan dan membentuk kelompok seni anakanak. Kegiatannya difokuskan pada seni dolanan anak-anak yang memadukan antara tarian dan seni suara lagu dolanan anak. Antusias peserta sangat luar biasa karena mereka datang dan berpartisipasi dalam jumlah besar, sehingga diperlukan teknik dan strategi khusus dari tim.

Setelah melalui pelatihan singkat, terbentuklah seni pertunjukan kelompok anakanak secara kolosal berupa seni drama kolosal. Bentuk pertunjukannya memadukan antara tari, drama, dan nyanyian. Materinya dari cerita-cerita yang ada di sekitarnya.

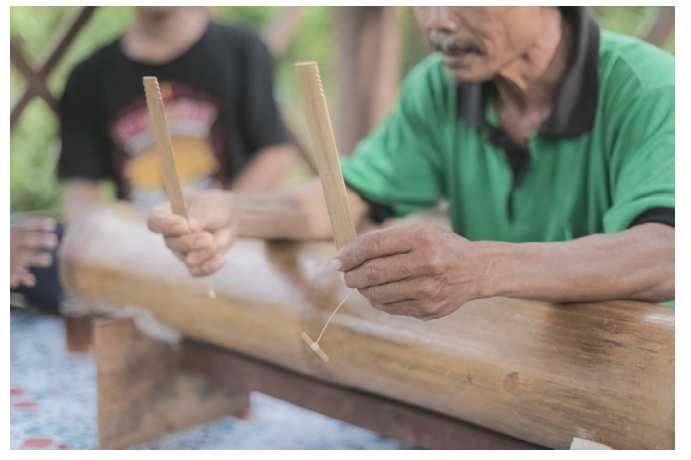

Foto 5. Seni musik Rinding Gumbeng Desa Beji Ngawen Gunungkidul

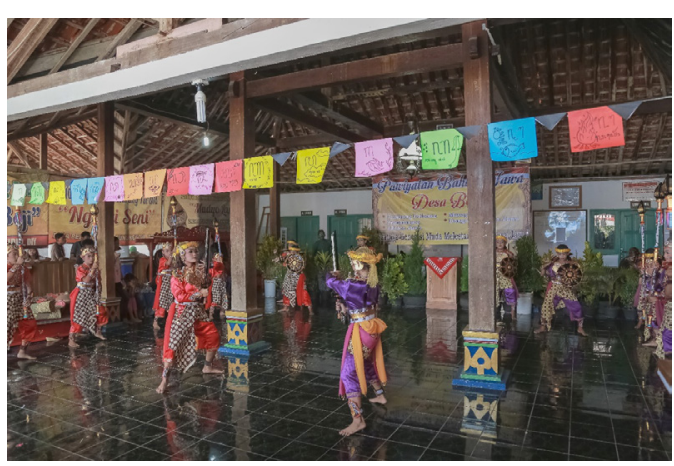

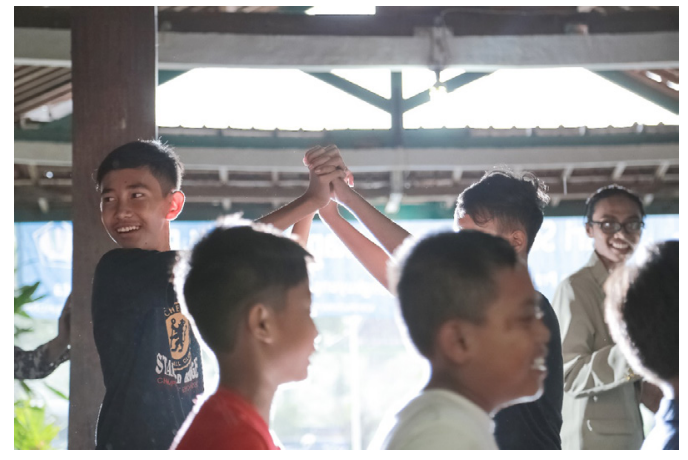

Foto 6. Keceriaan Anak-Anak berlatih Seni Dolanan Anak

Foto 7. Penampilan Pentas Drama kolosal kelompok seni AnakAnak dan Remaja Desa Beji 


\subsection{Keberlanjutan}

Kegiatan pengabdian pada masyarakat oleh Perguruan Tinggi harus dipersiapkan secara matang, terprogram, terintegrasi, dan ada keberlanjutan. Untuk menjaga keberlanjutan program, tim pengabdian Prodi Sastra Jawa merancang tiga kegiatan yang menyertai pelaksanaan pengabdian, yaitu menyusun sub tim yang membuat dokumen Pencatatan Organisasi Kelompok Seni Pertunjukan Desa Beji, sub tim untuk membuat dokumen Penulisan Cerita Rakyat Desa Beji, dan satu sub tim lagi untuk membuat dokumentasi Kegiatan adat dan tradisi di Desa Beji.

Kegiatan pengabdian di bidang ini harus dilakukan secara berkelanjutan. Pendampingan dalam kegiatan pengabdian kepada masyarakat yang sejalan dengan bidang keilmuan program studi dilakukan dengan memberikan edukasi yang kontinyu. Kegiatan pengabdian kepada masyarakat lebih bermanfaat apabila dilakukan juga research action (riset aksi) sebagai pengembangan bidang keilmuan yang relevan. Memperluas jangkauan obyek pengabdian dan mengintegrasikan dengan visi misi prodi. Bentuk kegiatan pengabdian kepada masyarakat harus dilakukan dengan inovatif dan kreatif

\section{Penutup}

Partisipasi aktif warga masyarakat dalam kegiatan ini menjadi kunci suksesnya penyelenggaraan pengabdian pada masyarakat. Persiapan yang matang dan pemahaman karakter masyarakat yang menjadi sasaran merupakan modal untuk jaminan sukses kegiatan. Masyarakat masih bersemangat dalam mewujudkan desa Berbudaya Jawa yang lestari dengan meperbaiki serta meningkatkan sumberdaya manusia.

Kesadaran masyarakat terkait potensi dan permasalahan yang ada di Desa Beji dalam bidang seni budaya Jawa telah terbangun sehingga arah dan tujuan pengembangan sudah lebih jelas. Pendampingan, pelatihan-pelatihan dalam pengembangan potensi ini masih perlu dilakukan agar masyarakat memiliki kemampuan pengembangan wisata seni budaya yang baik dan tidak berhenti dalam waktu pendek. Perbaikan sarana dan prasarana pendukung menuju Desa Berbudaya Jawa masih perlu ditingkatkan, sehingga diperlukan tim pendamping yang bekerja lebih intensif hingga terwujud masyarakat yang mandiri dalam mengelola potensi seni budaya yang dimilikinya.

\section{Daftar Pustaka}

Badan Pusat Statistik. (2015). Kecamatan Ngawen Dalam Angka 2015. BPS: Yogyakarta. Direktorat Pengabdian Kepada Masyarakat UGM. (2017). Indonesian Journal of Community Engagement (Jurnal Pengabdian Kepada Masyarakat), Volume 02, Number 2 Maret 2017. Yogyakarta.

Suliantoro, B.W. (2014). Kearifan Lokal Masyarakat Desa Beji Dalam Pemanfaatan Hutan Wonosadi. RESPONS Vol.19: 57-77.

Tim Pengabdian Prodi Sastra Jawa. (2017). "Pengembangan Potensi Bidang Bahasa, Seni Sastra, dan Seni Pertunjukan di Desa Beji Kecamatan Ngawen Kabupaten Gunungkidul Provinsi Daerah Istimewa Yogyakarta menuju Desa Berbudaya Jawa”. Laporan Kegiatan Pengabdian Pada Masyarakat Prodi Sastra Jawa Departemen Bahasa dan Sastra UGM. 
Winastuti, dkk. (2016 dan 2017). "Pengembangan TAHURA Wonosadi Desa Beji, Kecamatan Ngawen Gunungkidul untuk Peningkatan Potensi Ekonomi melalui Wanawisata berbasis Budaya Lokal” Laporan Pengabdian pada Masyarakat. DPKM UGM Tahun 2016 dan 2017. 